\title{
Increasing Nitrogen Availability for Rice Growth in Irrigated System in Sourou Valley (Burkina Faso)
}

\author{
Bandaogo Alimata ${ }^{1}$, Fofana Bidjokazo ${ }^{2}$, Sansan Youl $^{3}$ \\ ${ }^{1}$ Department of Natural Resource Management/ Production Systems, INERA, Bobo-Dioulasso Burkina Faso. 01 BP 910 \\ Bobo Dioulasso 01 \\ ${ }^{2}$ Sasakawa Africa Association Crop Productivity Enhancement,Addis Ababa, Ethiopia.P.O. Box 24135 Code 1000 \\ ${ }^{3}$ International Fertilizer Development Center, Ouagadougou, Burkina Faso. 11 BP 82 Ouagadougou 11
}

\begin{abstract}
Nitrogen is the main nutrient that is limiting yield in irrigated rice (Oryza sativa L.) systems. The availability of $N$ can affect phosphorus and potassium plant uptake and reduce rice yieldsThe effect of fertilizer nitrgogen $(N)$ (prilled urea PU) and briquettes-urea supergranules (USG) on rice nitrogen, phosphorus and potassium uptake, soil total $N$ were investigated in Sourou valley in Burkina Faso in pot experiment the dry season of 2013 on acid soil and alkaline soil. Pot experiment was carried out using a factorial design with the rice variety FKR62N.Field experiment was also carried out in the wet season 2013 in acid soil with two rice varieties (FKR 19 and FKR 62N) using a split plot design.The results indicate that soil total $N$ was higher in the acid soil compared to the alkaline soil during the panicle and flowering stages. Urea Deep Placement (UDP) significantly increased $N, P$ and $K$ uptake. Higher nitrogen content was recorded by urea deep placement with USG throughout the experiment. The amount of total $N, P$ and $K$ increased in rice plant with the UDP during the study.Field experiment also showed that USG application was $13 \%$ superior to PU application and gave more yields with the two varieties. The best combination was obtained with rice variety FKR $62 N$. This study suggests that farmers may derive more yields from the use of USG technology than broadcasting.
\end{abstract}

Keywords - Rice, urea supergranule, nutrient uptake, acid soil and alkaline soil.

\section{INTRODUCTION}

Nitrogen is very essential for thegrowth and development of crops. Unfortunately nitrogen is a limiting nutrient in irrigated rice in Burkina Faso (Segda 2006).The efficiency of fertilizer $\mathrm{N}$ use is generally low for lowland rice crop as only $30 \%$ of applied $\mathrm{N}$ is utilized by crops and the remaining $70 \%$ is lost through various processes causing serious environmental problems (Craswell andVlek 1979; Jiang et al. 2005).Soil infertility is a constant threat to sustainability of irrigated rice cultivation. The inerrant low contains of soil $\mathrm{N}$ leads to low efficiency of others nutrients that are $\mathrm{P}$ and $\mathrm{K}$ (Rabat 2003). Nitrogen and phosphorus fertilizers are major essential plant nutrients and key input for increasing crop yield (Dastanet al.2012; Yoseftabar 2012). N derived from fertilizer in rice plants are in the range of $18.7 \%$ to $40.0 \%$ in all plant tissues. The remaining $\mathrm{N}$ was derived fromsoil (Maqsood, 2016). They are fundamental to crop development because they form the basic component of many organic molecules, nucleic acids and proteins (Lea and Miflin 2011).Management practices with long term use of ammonium-based fertilizer can induce soil acidity (Singh, 2015). Soil pH is a critical indicator of nutrient availability. Soil reaction is not a growth factor as such but it is a good indicator of several key determinants of growth factors, especially nutrient availability. The nutrient absorption amount varies with rice growth stage. Absorption is low at the seedling stage and peaks before the heading stage, and then decreases as root activity declines (Guindoet al. 1994; Liuet al. 2007). The optimum $\mathrm{pH}$ for rice growth ranges between 5.5 and 7.0 (FAO 2006). Phosphorus is available at a slightly acidic or neutral $\mathrm{pH}$. High soil $\mathrm{pH}$ is also known to affect the efficiency of $\mathrm{N}$ fertilizers (Dobermann and Fairhurst 2000). Deep placement of urea supergranules has been shown to effectively reduce $\mathrm{N}$ loss (Mohammad, 2015) and increase rice yield on near neutral $\mathrm{pH}$ soils with alkaline floodwater (Singh 2005; Caiet al. 2002). However, floodwater also increases $\mathrm{pH}$ in acid soils and decrease $\mathrm{pH}$ in alkaline soils (Dobermann and Fairhurst 2000).To achieve rice production targets, balanced and adequate use of $\mathrm{P}$ and Kfertilizers as well as $\mathrm{N}$ is essential.Information on the response of irrigated rice systems on the technology of urea deep placement with urea supergranules is very limited in Burkina Faso. 


\section{MATERIALS AND METHODS}

Experimental site

The study was carried out in Sourou Valley in the dry season of 2013. The valley is an intensively cultivated area with a potential irrigated land of about 615,000 ha. The irrigation water is supplied by Sourou River with a capacity of $600,000,000 \mathrm{~m}^{3}$. The geographic coordinates are $13^{\circ} 00^{\prime}$ latitude North $03^{\circ} 20^{\prime}$ longitude west. The region of Sourou is characterized by a north Soudaniansahelian climate with an average rainfall below $900 \mathrm{~mm}$. Temperature are stable and between a minimum of $17^{\circ} \mathrm{C}$ in coolest season and maximum of $41^{\circ} \mathrm{C}$ in hottest season. The soils in Sourou Valley are mainly brown, poorly developed, hydromorphic soils and Vertisols with fine texture, high water retention capacity, low permeability, poor ventilation of subsurface horizons and strong compaction (Faggi and Mozzi2000). Two types of soils were used for the pot experiment were slightly acidic and alkaline with low organic matter content and low total nitrogen (Table 1). Soils used the study were cambisols.

\section{Experimental design}

Pot experiment was carried out using a factorial design with the rice variety FKR62N. The first factor was the type of soil (acidic and alkaline) and the second factor was the type of urea fertilizer (prilled urea - PU and urea supergranules- USG at the same rate of $52 \mathrm{~kg} \mathrm{~N}^{-1}$ and the control). Each treatment was replicated 16 times for 4 sampling per treatment at different stages (tillering, panicle initiation, flowering and maturity) of rice growth. Plastic pots of 25 liters were filled with $10 \mathrm{~kg}$ of soil from Sourou valley. The soils were wetted during 4 days before transplanting and four plants of rice from thirty (30) days seedlings were transplanted into each pot. A recommended rate of phosphorus $\left(69 \mathrm{~kg}\right.$ of $\left.\mathrm{P}_{2} \mathrm{O}_{5} \mathrm{ha}^{-1}\right)$ and potassium ( $24 \mathrm{~kg}$ of $\mathrm{K}_{2} \mathrm{O} \mathrm{ha}^{-1}$ ) were applied uniformly to all pots except the control at transplanting, as basal in the form of triple superphosphate and muriate of potash respectively. One granule of $1.8 \mathrm{~g}$ corresponding to $52 \mathrm{~kg}$ $\mathrm{N} \mathrm{ha}{ }^{-1}$ was placed seven days after transplanting between four plants in the pot receiving USG. The prilled urea at the same rate was split into two. The first half was applied 14 day after transplanting and the second half during panicle initiation. Irrigation of the pots was done when necessary.

\section{Plant sampling and analysis}

Plant biomass was taken at tillering, panicle initiation, flowering and at maturity. At each stage, four (4) pots of each treatment were destroyed. Rice plants were removed and the roots were washed to remove the remainningsoil. Plant biomass and roots were then cut and air dried for two weeks. The samples from each pot were weighed before and after drying. Soil and plant samples were taken during the different stages of rice growth and analyzed for total N. Plant N, P and K contents were calculated by multiplying $\mathrm{N}, \mathrm{P}$ and $\mathrm{K}$ concentrations by plant biomass weight at each stage.

\section{Data analysis}

Repeated measurement was conducted with Genstat package edition 9th to determine the significance of the effects of $\mathrm{N}$ fertilization. Analysis of variance was conducted to determine significance among yields. Treatment means were compared with the least significant different (Lsd) at the probability of 0.05. Graphical presentations were done using Excel software.

\section{RESULTS}

Soil total $\mathrm{N}$ increased until maturity with the use of urea fertilizer. Soil total $\mathrm{N}$ of the control increased quickly from flowering stage to maturity (Fig 1). The highest $\mathrm{N}$ contents were recorded with the USG treatment. Significant difference $(\mathrm{P}<0.05)$ was observed between acidic and alkaline soils. Whereas $\mathrm{N}$ content in the acid soil tended to increase until flowering, $\mathrm{N}$ content in the alkaline soil tended to stabilize at this stage but remained below $\mathrm{N}$ curve with acid soil (Fig 2). After the flowering stage, $\mathrm{N}$ content in acid soil decreased but $\mathrm{N}$ content in alkaline soil increased until maturity.

During rice growth $\mathrm{N}$ uptake increased until flowering and then decreased towards maturity with USG and PU treatments. Nitrogen uptake was higher when rice was treated with USG than PU and the control (Fig 3). The peak values at flowering with USG and PU were 1.813 and $0.689 \mathrm{~g} \mathrm{pot}^{-1}$, respectively. Nitrogen uptake with the control was stable throughout the growing period. The lowest $\mathrm{N}$ uptake was recorded with the control. Nitrogen uptake patterns were similar in acid and alkaline soils. During rice growth stages, plant $\mathrm{N}$ uptake increased and a peak was observed at flowering stage in both soils (Fig 4). After this stage, plant $\mathrm{N}$ uptake decreased in both soils until rice maturity. Plant $\mathrm{N}$ uptake was also significantly greater in the acid soils at rice tillering, panicle initiation and at flowering stages than in the alkaline soils.

The use of USG increased P uptake of rice sharply from tillering to flowering where it attained a peak of $0.418 \mathrm{~g}$ pot $^{-1}$ and then declined. A similar pattern was obtained in $\mathrm{P}$ uptake with PU treatment which rose up until panicle initiation with a peak value of $0.257 \mathrm{~g}^{-1}$ and then declined until rice maturity. Lowest $\mathrm{P}$ uptake was observed with the control which fluctuated during rice growth stages (Fig 5). The highest $\left(0.303 \mathrm{~g} \mathrm{pot}^{-1}\right)$ and the lowest $\left(0.021 \mathrm{~g} \mathrm{pot}^{-1}\right) \mathrm{P}$ uptake were recorded on the acid and the alkaline soils, respectively. Rapid P uptake was observed after rice tillering until panicle initiation and at flowering in the alkaline soil and the acid soil (Fig 6), 
respectively. After these growth stages rapid decline was observed in $\mathrm{P}$ uptake in both soils until rice maturity.

Similar K uptake patterns were observed with the use of PU and USG at the different stages of rice growth except before the PI growth stage (Fig 7). Significant difference ( $\mathrm{P}<0.05)$ was observed in $\mathrm{K}$ uptake with the treatments (Table 2). Potassium uptake decreased after tillering until panicle initiation. At this stage $\mathrm{K}$ uptake rose up at flowering and declined until rice maturity in both soils. The highest $\mathrm{K}$ uptake was observed at flowering $(2.123 \mathrm{~g}$ $\left.\operatorname{pot}^{-1}\right)$ and at tillering $\left(2.045 \mathrm{~g} \mathrm{pot}^{-1}\right)$ with USG and PU, respectively. Potassium uptake with the control declined after tillering stage and remained stable at panicle initiation and flowering. An increased was observed at rice maturity in $\mathrm{K}$ uptake with the control. Potassium uptake in the two types of soils followed the same patterns as nitrogen uptake (Fig 8). Potassium uptake was significantly $(\mathrm{P}<0.05)$ higher during rice growth in acid than alkaline soil.

\section{Rice yields}

Nitrogen treatment significantly $(\mathrm{P}<0.001)$ affected rice grain and straw yields. Grain yield was higher when USG was applied (Tableau 2). The increased in grain yield when USG and PU were applied over the yield of the control was $55 \%$ and $37 \%$, respectively.Higher straw yield was also observed with USG application $(5182 \mathrm{~kg}$ $\mathrm{ha}^{-1}$ ). Rice variety FKR $62 \mathrm{~N}$ gave $11 \%$ more grain and straw yields compare to rice variety FKR 19 . The best interaction was obtained with rice variety FKR $62 \mathrm{~N}$ using USG.

\section{DISCUSSION}

Effect of urea fertilizer and soil types on soil total nitrogen

Nitrogen availability varied with soil $\mathrm{pH}$ during the study. Soil $\mathrm{N}$ was higher in the acid soil compared to the alkaline soil during the panicle and flowering stages. This result can be explained by the fact that nitrogen loss may be high in the alkaline soil due to high soil $\mathrm{pH}$. Ammonia losses from floodwater may reduce soil nitrogen availability. In fact, the conversion of $\mathrm{NH}_{4}{ }^{+}$to $\mathrm{NH}_{3}$ is governed by soil $\mathrm{pH}$. During urea hydrolysis the $\mathrm{pH}$ surrounding the granule initially rises $(\mathrm{pH}>8)$ as ammonium bicarbonate is formed. Longo and Melo (2005) measured the rate of urea hydrolysis under laboratory conditions using a range of soil $\mathrm{pH}$ from 2.2 to 8.0. According to their finding, as the soil $\mathrm{pH}$ increased the rate of urea hydrolysis increased almost exponentially. They also found that the highest rate of urea hydrolysis was at $\mathrm{pH}$ 8.0. Similar results were reported by Vlek and Craswell (1981) and Fillery et al. (1986). At rice maturity, soil $\mathrm{N}$ increased in the alkaline soil and declined in the acid soil. However,soil $\mathrm{N}$ remained higher acid soil than alkaline soil.

The type of urea fertilizer significantly affected soil total nitrogen. The use of USG increased soil total $\mathrm{N}$ more than PU urea. This can be attributed to the fact that USG can be considered slowly available $\mathrm{N}$ fertilizer that provides $\mathrm{N}$ to meet plant requirements (Savant and Stangel1990).Higher nitrogen content was recorded by urea deep placement with USG throughout the experiment. This result can also be attributed to the incorporation of nitrogen that reduced $\mathrm{N}$ losses via volatilization and denitrification and optimized nitrogen availability in soil (Choudhury et al. 1997; De Datta 1981).

Effect of soil and urea fertilizer types on $\mathrm{N}, \mathrm{P}$ and $\mathrm{K}$ uptake

The amount of total $\mathrm{N}, \mathrm{P}$ and $\mathrm{K}$ increased in rice plant with the urea deep placement (UDP) during the study. The results are in agreement with findings of Bowen et al. (2004) and Pasandaran et al. (1999) and Bandaogo et al. 2014, who reported that urea deep placement technology was highly effective in improving crop uptake of applied $\mathrm{N}$ fertilizers in irrigated rice system in Asia. The results can be attributed to the decrease of soil $\mathrm{N}$ loss with USG deep placement observed in pot experiment. According to the study of De Datta (1986), the use of urea supergranules could synchronise $\mathrm{N}$ release with plant requirements and provide sufficient $\mathrm{N}$ in a single application to satisfy plants' requirements while maintaining mineral $\mathrm{N}$ in the soil throughout the growing season. The increase in $\mathrm{P}$ and $\mathrm{K}$ uptake with USG can also be explained by the interdependence between $\mathrm{N}, \mathrm{P}$ and $\mathrm{K}$ as reported by Rabat (2003). It is known that $\mathrm{N}$ is a limiting factor in irrigated rice systems (Segda 2006); its availability also increases phosphorus and potassium uptake. As P is relatively immobile in soils, and roots can deplete $\mathrm{P}$ only from a distance that coincides approximately with the length of the root hair. This finding is in agreement with the findings of Savant and Stangel (1990) who reported that rice roots tend to proliferate near the placement point of urea supergranule and to increase during many weeks after urea placement.

Soil type also affected N, P and K uptake. Nutrient uptake was higher in the acid soil and this can be explained by the fact that $\mathrm{pH}$ increase inhibits root proliferation as reported by Shaaban et al. (2013). The lower density of roots in the alkaline soil could affect the uptake of nutrients. The rise in $\mathrm{pH}$ increased the rate of ammonium conversion to ammonia, which increased its volatilization. Deep placement of urea supergranules has been shown to effectively reduce $\mathrm{N}$ loss and increase rice yield on near neutral $\mathrm{pH}$ soils with alkaline floodwater (Singh 2005, Maqsood 2016 and Cai et al. 2002). 
Effect of USG on grain yield

Rice grain yield significantly increased with the use of USG even with the two type of rice varieties used. This result can be explained by the findings of pot experiment which showed that USG increase soil $\mathrm{N}$ and increase $\mathrm{N}$ availability for rice plant. Pot experiment also showed that application of USG increased $\mathrm{P}$ and $\mathrm{K}$ uptake that are very essential for rice plant development. This result is in agreement with finding of Bandaogo (2014) who showed USG increased rice grain yield by $12 \%$ compared to PU.

\section{CONCLUSION}

USG technology was more effective with acid soil than alkaline soil. Pot experiment indicated that soil total nitrogen, plant nitrogen uptakewere higher in acid soil than alkaline soil. This result confirmed that USG can provide sufficient $\mathrm{N}$ in a single application to satisfy the plant's needs and increase plant nitrogen uptake and also confirmed that the performance of USG is greater in acid soil compared to PU.This study suggests that urea super granule can be used by farmers to improve nitrogen use efficiency and increase grain yields in the irrigated rice cropping system.

Acknowledgments

The authors are grateful to Alliance for Green Revolution in Africa (AGRA) and International Fertilizer

Table.2: Effect of urea fertilizer type on rice grain and straw yields

\begin{tabular}{|c|c|c|c|c|}
\hline \multirow[t]{2}{*}{ Treatment } & \multicolumn{2}{|c|}{ Grain yield } & \multicolumn{2}{|c|}{ Strawyield } \\
\hline & $\left(\mathrm{kg} \mathrm{ha}^{-1}\right)$ & $\begin{array}{l}\text { Increase over } \\
\text { control } \\
(\%)\end{array}$ & $\left(\mathrm{kg} \mathrm{ha}^{-1}\right)$ & $\begin{array}{l}\text { Increase over control } \\
(\%)\end{array}$ \\
\hline \multicolumn{5}{|l|}{ Type of urea } \\
\hline Control & 1774 & - & 3021 & - \\
\hline PU & 2439 & 37.49 & 4771 & 57.93 \\
\hline USG & 2746 & 54.79 & 5182 & 71.53 \\
\hline $\operatorname{Lsd}(5 \%)$ & 264 & - & 633 & - \\
\hline Fpr & 0.001 & - & 0.001 & - \\
\hline \multicolumn{5}{|l|}{ Variety } \\
\hline FKR 19 & 2194 & - & 4297 & - \\
\hline FKR 62N & 2445 & - & 4352 & - \\
\hline Lsd (5\%) & 199.5 & - & 696.5 & - \\
\hline Fpr & 0.028 & - & 0.819 & - \\
\hline \multicolumn{5}{|c|}{ Variety $\times$ type of urea } \\
\hline \multicolumn{5}{|c|}{ FKR19×Control } \\
\hline FKR19 × PU & 1975 & - & 3187 & - \\
\hline FKR19 $\times$ USG & 2112 & 6.49 & 4790 & 50.30 \\
\hline FKR62N×Control & 2495 & 26.33 & 4915 & 54.22 \\
\hline $\mathrm{FKR62N} \times \mathrm{PU}$ & 1574 & - & 2854 & - \\
\hline $\mathrm{FKR62N} \times \mathrm{USG}$ & 2766 & 75.73 & 4752 & 66.50 \\
\hline $\operatorname{Lsd}(5 \%)$ & 2996 & 90.34 & 5450 & 90.96 \\
\hline Fpr & 327 & - & 858 & - \\
\hline \multirow[t]{2}{*}{$\mathrm{CV}(\%)$} & 0.002 & - & 0.348 & - \\
\hline & 10.5 & - & 13.4 & - \\
\hline
\end{tabular}

Development Center (IFDC) for financing this study. We also like to thank to the Institute of Environment and Agronomic Research of Burkina Faso (INERA) for the technical support.

Illustrations of tables

Table.1: Initial soil chemical and physical characteristics.

\begin{tabular}{lll}
\hline Soilproperty & Acid soil & Alkaline soil \\
& & \\
\hline Clay $(\%)$ & 37.70 & 19.61 \\
Silt $(\%)$ & 21.50 & 45.10 \\
Sand $(\%)$ & 40.80 & 35.29 \\
Organic carbon $(\%)$ & 1.53 & 1.33 \\
Total N $(\%)$ & 0.11 & 0.09 \\
C/N & 14.00 & 15.00 \\
AvailP $(\mathrm{mg} / \mathrm{kg})$ & 4.56 & 5.05 \\
pH $\left(1: 2.5 \mathrm{H}_{2} \mathrm{O}\right)$ & 6.30 & 8.02 \\
\hline
\end{tabular}


Illustrations of figures

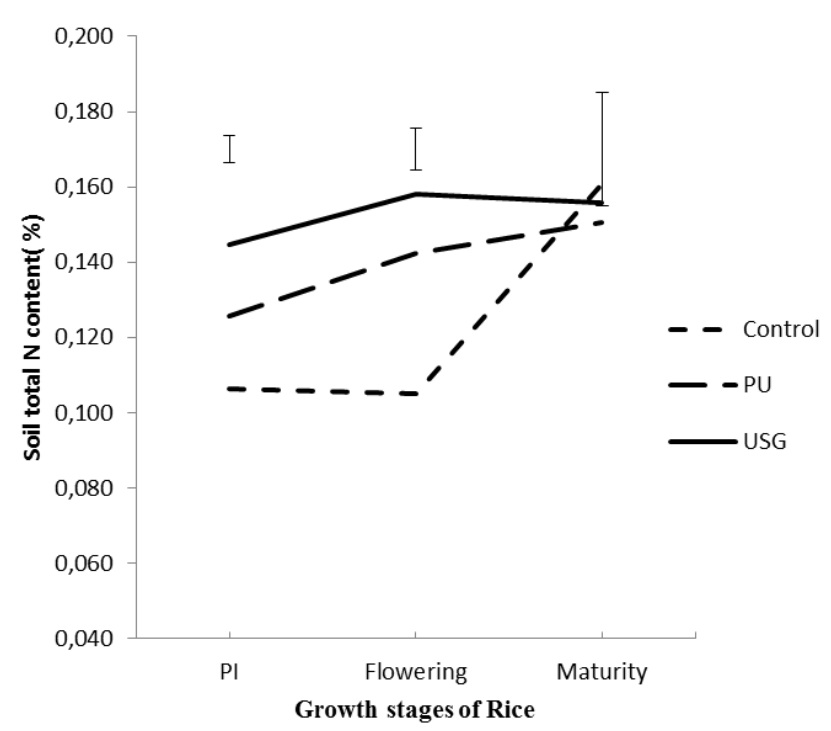

Fig. 1: Soil total $N$ content at different rice growth stages as affected by type of urea fertilizers. $\mathrm{PI}=$ panicle initiation and bars indicate Lsd $(5 \%)$
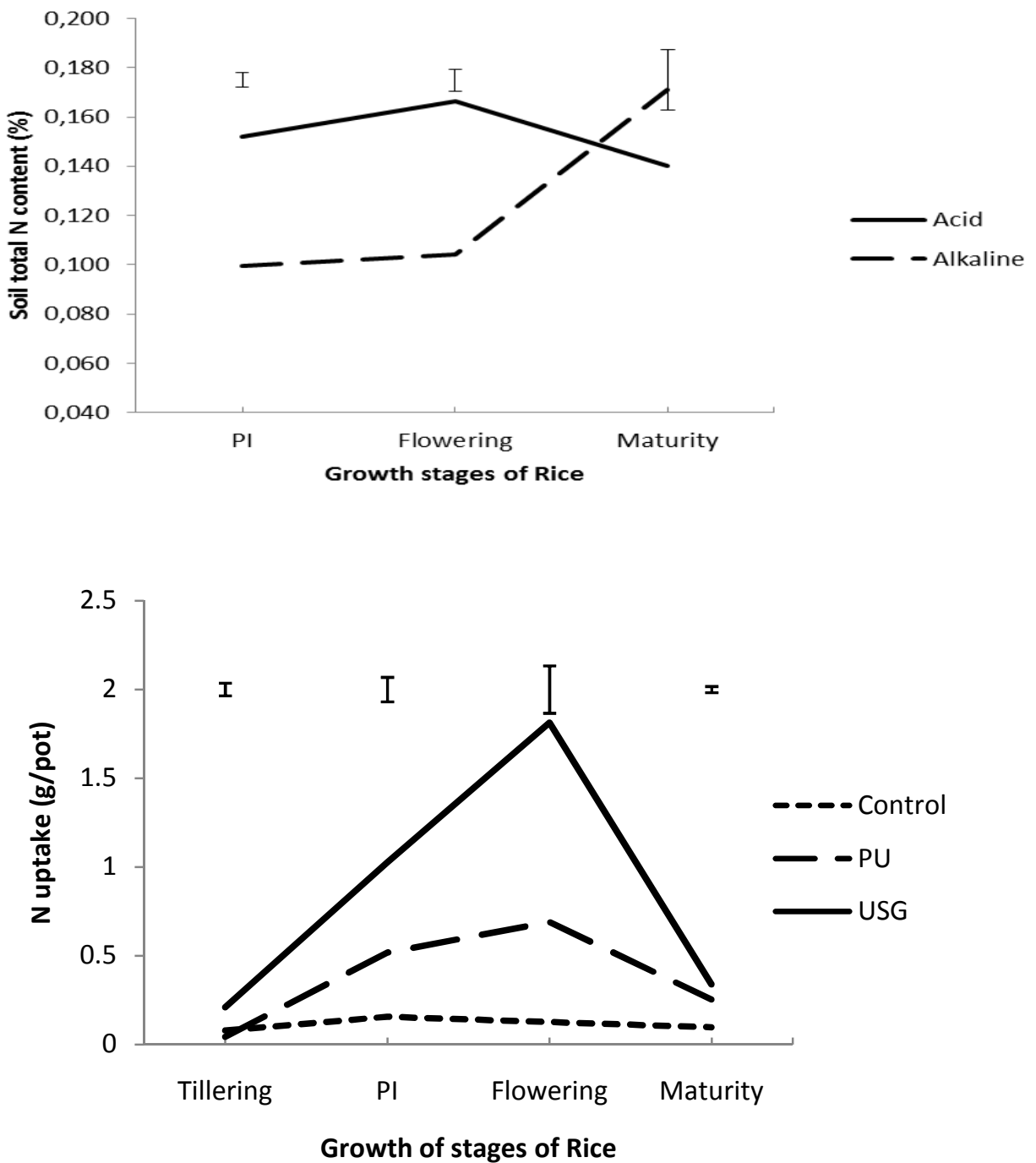

Fig.3: Nitrogen uptake at different rice growth stages as affected by type of urea fertilizers. 


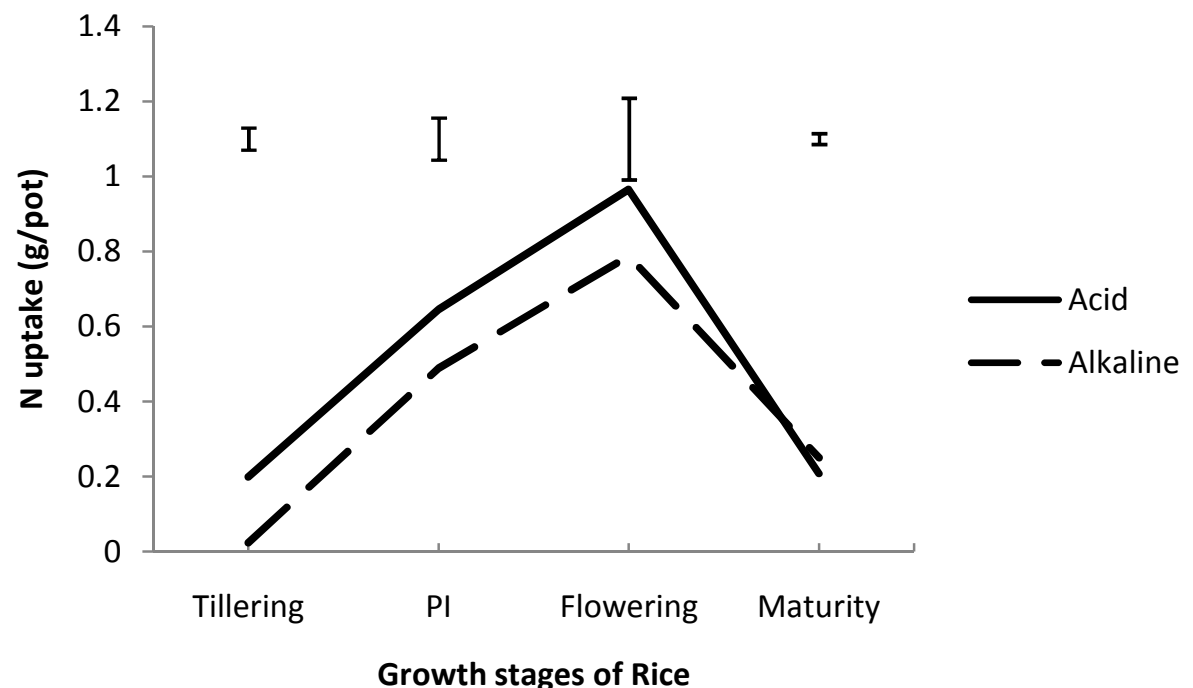

Fig.4: Nitrogen uptake at different rice growth stages as affected by soil $\mathrm{pH}$.

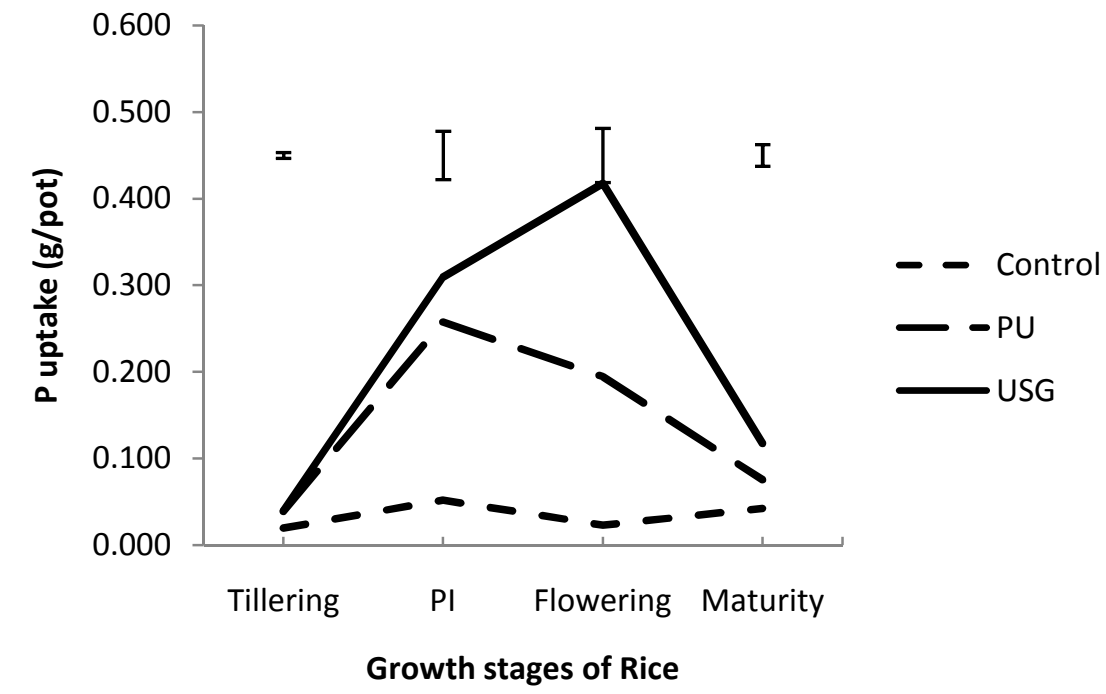

Fig.5: Phosphorus uptake at different rice growth stages as affected by type of urea fertilizers.

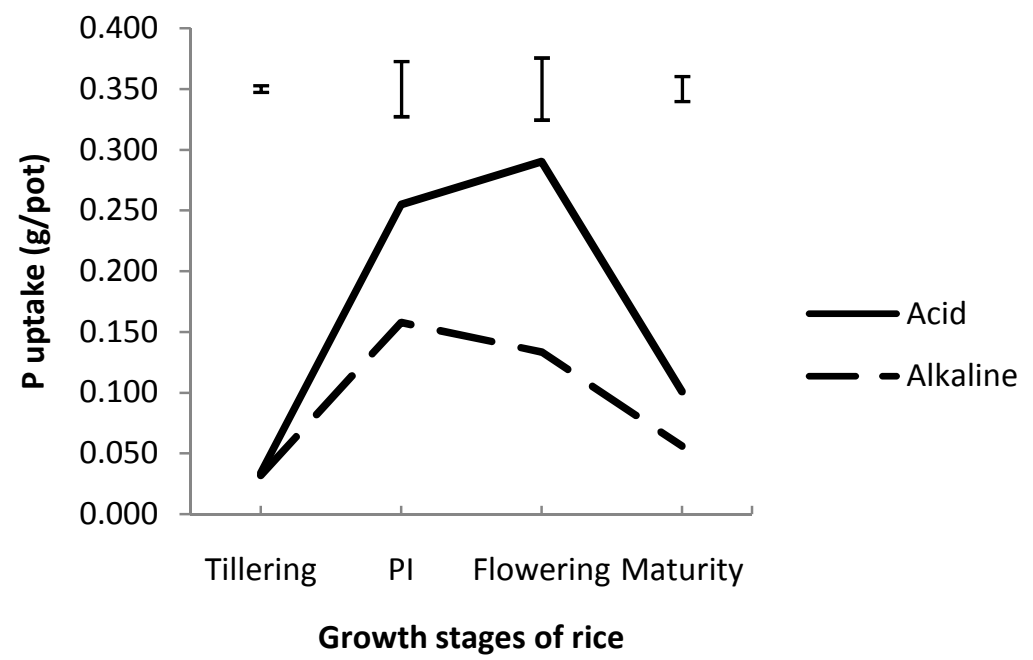

Fig.6: Phosphorus uptake at different rice growth stages as affected by soil $\mathrm{pH}$. 


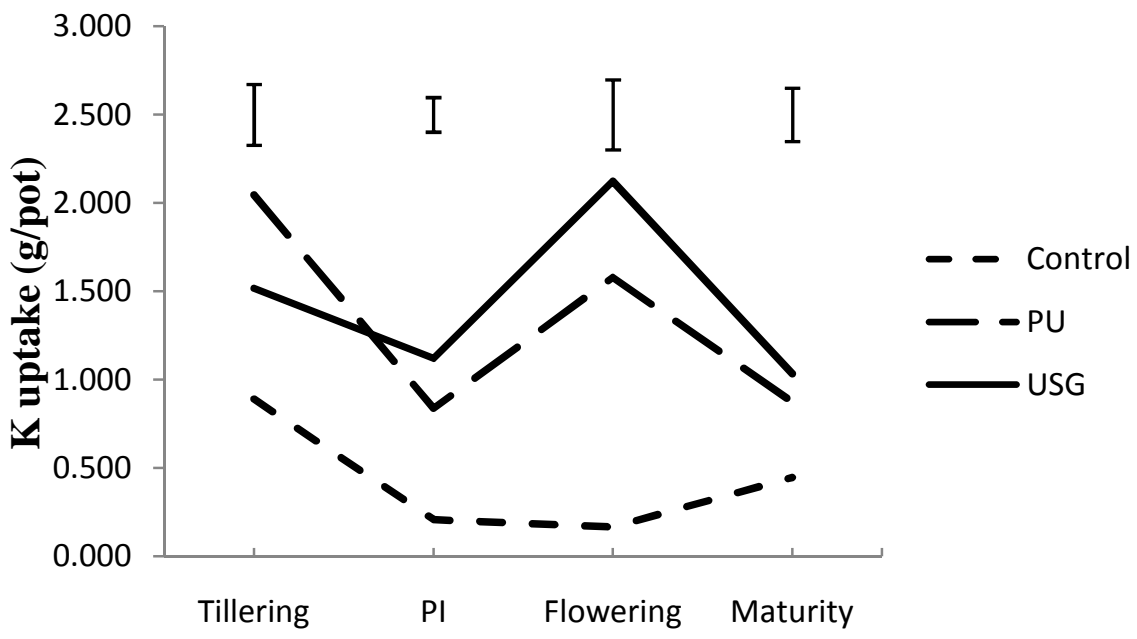

Growth stages of Rice

Fig.7: Potassium uptake at different rice growth stages as affected by type of urea fertilizers.

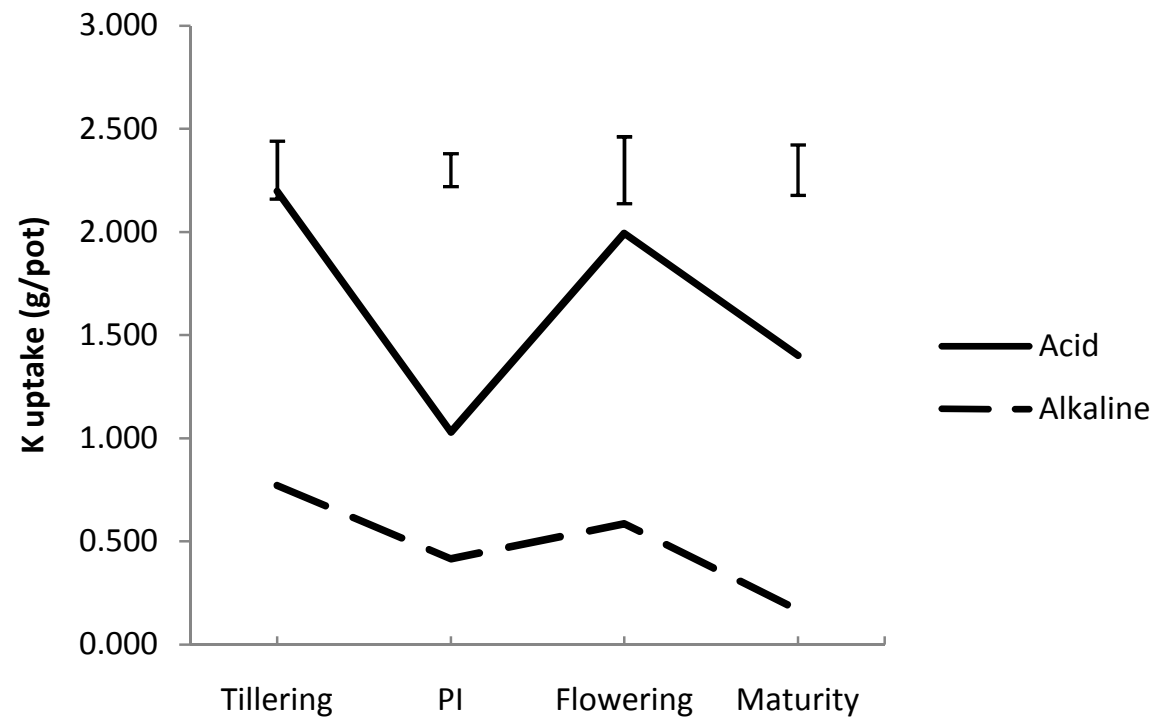

Growth stages of Rice

Fig.8: Potassium uptake at different rice growth stages as affected by soil pH.

\section{REFERENCES}

[1] Bandaogo A, Fofana B, Youl S, AbaidooRC, SafoEY,OpokuA (2014). Effect of fertilizer deep placement with urea supergranuleon nitrogen use efficiency of irrigated rice in Sourou Valley (Burkina Faso). Nutrient Cycling in Agroecosystems 102 (2): 79-89.

[2] Bowen WT, Diamond RB, Singh U, Thompson TP (2004). Urea deep placement increases yield and save Nitrogen fertilizer in farmer's field in Bangladesh. Rice in life: Scientific Perspectives for the 21st Century" In: Proc. World Rice Res. Conference held in Tsukuba, Japan, 4-7 Nov. 2004, pp. 369 - 372 .
[3] Cai GX, Chen DL, Ding H, Pacholski A, Fan XH, Zhu ZL (2002). Nitrogen losses from fertilizers applied to maize, wheat and rice in north China plain. Nutrient cycling in Agroecosystems 63: 187 195.

[4] Choudhury ATMA., Zaman SK, Bhuiyan NI (1997). Nitrogen response behavior of four rice varieties under wetland culture. Thai Journal of Agricultural Science 30: $195-202$.

[5] Craswell ET, Vlek PLG (1979). Fate of fertilizer nitrogen applied to wetland rice. In Nitrogen and Rice, pp. 175-192. IRRI, Los Baños. Philippines.

[6] Dastan S, Siavoshi M, Zakavi D, Ghanbariamalidarreh A, Yadi R, Ghorbannia DE, Nasiri AR (2012). Application of nitrogen and silicon rates on 
morphological and chemical lodging related characteristics in rice (Oryza sativa L.) North of Iran. Journal of agricultural Science 4(6): $1-18$.

[7] De Datta SK, Patrick WHJr (1986). Nitrogen Economy of Flooded Rice Soils. MartinusNijhof Publishers, Dordrecht, the Netherlands.

[8] De Datta SK (1981). Principles and Practices of Rice Production; John Wiley and Sons, Inc., New York.

[9] Dobermann A, Fairhurst T (2000). Rice: NutrientDisorders and Nutrient Management, pp. 191.

[10]Faggi P, Mozzi, P (2000). La territorialisation hydraulique dans la Vallée du Sourou (Burkina Faso). Université de Padova, Italia, pp 78.

[11]FAO (2006). Plant nutrition for food security. A guide for integrated nutrient management. Viale delle Terme di Caracalla00100 Rome, Italy. pp 368.

[12]Fillery IRP, Roger PA, De Datta SK (1986). Ammonia Volatilization from Nitrogen Sources Applied to Rice Fields. Soil Science Society of America Journal 50: 86 - 91.

[13] Guindo D, Wells BR, Norman RJ(1994). Cultivars and nitrogen rate influence on nitrogen uptake and partitioning in rice.Soil Science Society of America Journal,58(3): 840-849.

[14]Jiang L, Dong D, Gan X, Wei S (2005). Photosynthetic efficiency and nitrogen distribution under different nitrogen management and relationship with physiological nitrogen use efficiency in three rice genotypes. Plant Soil. 271: 321-328.

[15]Lea PJ,Miflin BJ (2011). Nitrogen assimilation and its relevance to crop improvement. Annual Plant Reviews, pp. 1-40.

[16]Liu LJ, Xu W, Wu CF, Yang JC(2007). Characteristics of growth, development and nutrient uptake in rice under site-specific nitrogen management. Chinese Journal Rice Science, 21(2): 167-173.

[17]Longo RM, Melo WJ (2005). Urea hydrolysis in oxisols: effects of substrate concentration, temperature, $\mathrm{pH}$, incubation time and storage. RevistaBrasiliera. Ciência do Solo. 24: 651 - 657.

[18] Maqsood AM, Awan KU, AzizT, ArshadH, Ashraf N,Ali M (2016). Nitrogen management in calcareous soils: problems and solutions. Pakistan Journal Agriculture Science, 53(1), 79-95.

[19] Mohammad MH, Mohd KY, Radziah O, Samsuri A(2015). Characterization of nitrogen uptake pattern in malaysian rice MR219 at different growth stages using ${ }^{15} \mathrm{~N}$ Isotope. Rice Science, 22(5): 250-254.

[20]Pasandaran EB., Gulton JS, Adiringsih RI, AspariH, Rochayati SR (1999). Government policy support for technology promotion and adoption: a case study of urea tablet technology in Indonesia. Nutrientcycling in Agroecosystems 53: 113 - 119.

[21] Rabat P (2003). Les engrais et leurs applications. Précis à l'usage des agents de la vulgarisation agricole, 4e édition. pp 77.

[22] Savant NK, Stangel PJ (1990). Deep placement of urea supergranules in transplanted rice: principles and practices. FertilizerResearch 25: $1-83$.

[23] Segda Z(2006). Gestion de la fertilité du sol pour une production améliorée et durable du riz (Orizasativa L.) au Burkina Faso. Cas de la plaine irrigué de Bagré. Thèse présentée à l'UFR/ SVT. ThèsedoctoratUniversité de Ouagadougou (Burkina Faso). pp 202 + publications.

[24] Shaaban M,AbidM, Abou-Shanab RAI (2013). Amelioration of salt affected soils in rice paddy system by application of organic and inorganic amendments. Plant Soil Environment 59(5): 227 233.

[25] Singh B, Ryan J(2015). Managing Fertilizers to Enhance Soil Health. First edition, IFA, Paris, France.pp 24

[26] Singh U (2005). Integrated nitrogen fertilization for intensive and sustainable Agriculture. Journal of Crop improvement 15 (2): 1 - 19.

[27] Vlek PLG, Craswell ET (1981) Ammonia volatilization from flooded soils. Fertility Research 2: 227 - 245.

[28] Yoseftabar S (2012). Effect of Nitrogen and Phosphorus Fertilizer on Growth and Yield Rice (Oryza Sativa L). International journal of Agronomy and Plant Production. 3 (12): 579 - 584. 